\title{
FAKTOR RISIKO MUSCULOSKELETAL DISORDERS (MSDS) PADA PEKERJA TENUN IKAT DI KELURAHAN TUAN KENTANG KOTA PALEMBANG
}

\author{
Sherli Shobur, ${ }^{1}$ Maksuk, ${ }^{1}$ Fenti Indah Sari, ${ }^{2}$ \\ ${ }^{1}$ Politeknik Kesehatan Kemenkes Palembang, Indonesia \\ ${ }^{2}$ Program Studi Kesehatan Masyarakat STIK Bina Husada Palembang, Indonesia \\ Korespondensi:maksuk@poltekkespalembang.ac.id
}

\begin{abstract}
Musculoskeletal Disorders (MSDs) are diseases that have symptoms that affect the muscles, nerves, tendons, joint ligaments, cartilage, and spinal nerves. This study aims to find out the analysis of musculoskeletal disorders (MSDS) in woven weaving workers in the village of Tuan KentangPalembang City in 2019. The research was conducted in May. The study was an observational analytic with design cross-sectional. The samples of this study were a total sampling of 44 workers, Data was collected with a questionnaire and Nordic Body Map. Data were analyzed using univariate and bivariate analysis with a significance level $(\alpha=0.05)$. The results of this study indicate that there is a relationship between age, length of work, length of service, repetitive activity and physical fitness and no sex relations with musculoskeletal disorders (MSDS) in tie weaving workers in the village of Tuan Kentang Palembang 2019. The results of this study indicate that there is a relationship between age, length of work, length of service, repetitive activity and physical fitness and no sex relations with musculoskeletal disorders (MSDS) in tie weaving workers in the village of Tuan Potat Palembang City in 2019
\end{abstract}

Keywords : Analysis, Musculoskeletal Disorders, Workers, Weaving

\begin{abstract}
ABSTRAK
Musculoskeletal Disorders (MSDs) adalah penyakit yang mempunyai gejala yang menyerang otot, syaraf, tendon, ligamen tulang sendi, tulang rawan, dan syaraf tulang belakang. Penelitian ini bertujuan diketahuinyaanalisis Musculoskeletal Disorders (MSDs) pada pekerja tenun ikat di kelurahan tuan kentang kota palembang tahun 2019. Desain penelitian ini adalah observasional analitik dengan pendekatan potong lintang. Sampel penelitian ini pekerja tenun ikat di Kelurahan Tuan Kentang Kota Palembang yang berjumlah berjumlah 44 orang. Instrumen penelitian menggunakan lembar Nordic Body Map. Analisis hubungan menggunakan Uji statistik chi square $(\alpha=0,05)$. Penelitian ini dilaksanakan pada 23 April 2019. Hasil analisis hubungan didapatkan nilai masing-masing variabel terhadap $M S D s$ adalah umur $(p=0,012)$, lama $\operatorname{kerja}(p=0,027)$, masa kerja $(p=0,027)$, aktivitas berulang $(p=0,012)$, kesegaran fisik $(p=0,027)$, jenis kelamin $(p=0,702)$. Sehingga dapat disimpulkan bahwa ada hubungan antara umur, lama kerja, masa kerja, aktivitas berulang dan kesegaran fisik serta tidak ada hubungan jenis kelamin dengan MSDs. Disarankan untuk lebih memperhatikan kesehatan dan keselamatan kerja pada pekerja terutama pada gangguan musculoskeletal disorders yang disebabkan karena kondisi lingkungan kerja dan beban kerja yang kurang sesuai sehingga dapat mengakibatkan menurunnya produktivitas kerja.
\end{abstract}

Kata Kunci $\quad$ : Analisis, Musculoskeletal Disorders, Pekerja, Tenun 


\section{PENDAHULUAN}

Tubuh manusia dirancang untuk dapat melakukan aktifitas pekerjaan sehari-hari, adanya masa otot yang bobotnya hampir lebih dari separuh berat tubuh memungkinkan kita untuk dapat menggerakan tubuh. Bekerja berarti tubuh akan menerima beban dari luar tubuhnya, beban tersebut dapat berupa beban fisik maupun beban mental. ${ }^{(1)}$

Keluhan Musculoskeletal Disorders adalah keluhan pada bagian-bagian otot skeletal yang dirasakan oleh seseorang mulai dari keluhan sangat ringan sampai sangat sakit. Apabila otot menerima beban statis secara berulang dan dalam waktu yang lama, akan dapat menyebabkan keluhan berupa kerusakan pada sendi, ligamen dan tendon. ${ }^{(2)}$

Satu pekerja di dunia meninggal setiap 15 detik karena kecelakaan kerja dan 160 pekerja mengalami sakit akibat kerja dan angka kematian dikarenakan kecelakaan dan penyakit akibat kerja (PAK) sebanyak 2 juta kasus setiap tahun. ${ }^{(3)}$ Masalah kesehatan di Indonesia menunjukkan bahwa sekitar $40,5 \%$ penyakit yang diderita pekerja berhubungan dengan pekerjaannya diantaranya penyakit MSDs sebanyak $16 \%{ }^{(4)}$.

Data dari Puskesmas Rumbio Jaya (2011), dalam pencatatannya menyebutkan terdapat 10 kasus penyakit pada pekerja informal yang terdiri dari penyakit gangguan sendi dan musculoskeletal, serta di posisi kedua dengan jumlah kasus 30 dari 146 kasus penyakit yang ada. Hal tersebut dapat menyebabkan masalah kecacatan seperti dislokasi tulang dan sendi. ${ }^{(5)}$ Muskuloskeletal disorders (MSDs) merupakan gangguan pada sistem muskuloskeletal yang disebabkan oleh pekerjaan dan performansi kerja seperti postur tubuh tidak alamiah, beban, durasi dan frekuensi serta faktor individu (usia, masa kerja, kebiasaan merokok, IMT dan jenis kelamin). ${ }^{(6)}$

Tenun merupakan salah satu seni budaya kain tradisional Indonesia yang diproduksi di berbagai wilayah seluruh Nusantara termasuk Kota Palembang. Tenun memiliki makna, nilai sejarah, dan teknik yang tinggi dari segi warna, motif, dan jenis bahan serta benang yang digunakan dan tiap daerah memiliki ciri khas masing-masing. Tenun sebagai salah satu warisan budaya tinggi (heritage) merupakan kebanggan bangsa Indonesia, dan mencerminkan jati diri bangsa. ${ }^{(7)}$

Berdasarkan pengambilan data awal, pekerja tenun ikat di Kelurahan Tuan Kentang Kota Palembang terdapat 7 rumah produksi tenun ikat, dimana dalam satu rumah produksi terdiri dari 5-8 pekerja. Kelurahan tuan kentang kota Palembang 
adalah wilayah industri tenun ikat, dari hasil pengamatan pada survey pendahuluan dikelurahan tuan kentang kota Palembang pekerja tenun ikat berkerja dengan kursi tanpa sandaran dengan gerakan kaki dan tangan yang berulang-ulang. Alat tenun dan tempat duduk dirancang dengan tidak memperhitungkan antropometri pekerja, sehingga pekerja harus menyesuaikan diri dan berkerja dengan punggung membungkuk. Kondisi seperti ini memaksa pekerja selalu berada pada sikap dan posisi kerja yang tidak ergonomis yang berlangsung lama dan menetap atau statis. Kondisi tersebut dapat menyebabkan terjadinya gangguan kesehatan, sikap kerja yang statis dalam jangka waktu yang lama lebih cepat menimbulkan keluhan pada sistem Musculoskeletal.

Penelitian ini bertujuan untuk menganalisis faktor risiko yang mempengaruhi keluhan Musculoskeletal Disorders (MSDs) pada pekerja tenun ikat di Kelurahan Tuan Kentang Kota Palembang.

\section{METODE}

Desain penelitian ini adalah observasional analitik dengan pendekatan potong lintang. Sampel penelitian ini pekerja tenun ikat di Kelurahan Tuan Kentang Kota Palembang yang berjumlah berjumlah 44 orang. Instrumen penelitian menggunakan lembar Nordic Body Map (NBM). Analisis hubungan menggunakan Uji statistik chi square $(\alpha=0,05)$. Penelitian ini dilaksanakan pada April - Mei 2019.

\section{HASIL DAN PEMBAHASAN}

Tabel 1 Distribusi Frekuensi Responden Berdasarkan Musculoskeletal Disorders (MSDs) pada Pekerja Tenun Ikat di Kelurahan Tuan Kentang Kota Palembang

Tahun 2019.

\begin{tabular}{lcc}
\hline $\begin{array}{c}\text { Musculoskeletal } \\
\text { Disorders } \\
(\text { MSDs })\end{array}$ & Jumlah & $\begin{array}{c}\text { Persentase } \\
(\%)\end{array}$ \\
\hline Berat & 35 & 79,5 \\
Ringan & 9 & 20,5 \\
\hline \multicolumn{1}{c}{ Total } & 44 & 100 \\
\hline
\end{tabular}

Tabel 2. Hubungan antara Umur dengan Musculoskeletal Disorders (MSDs) pada Pekerja Tenun Ikat di Kelurahan Tuan Kentang Kota Palembang Tahun 2019

\begin{tabular}{|c|c|c|c|c|c|c|c|}
\hline \multirow[t]{3}{*}{ Variabel } & \multicolumn{4}{|c|}{$\begin{array}{c}\text { Musculoskelet } \\
\text { al Disorders } \\
\text { (MSDs) }\end{array}$} & \multirow{2}{*}{\multicolumn{2}{|c|}{ Jumlah }} & \multirow[t]{3}{*}{$\begin{array}{c}p \\
\text { valu } \\
e\end{array}$} \\
\hline & \multicolumn{2}{|c|}{ Berat } & \multicolumn{2}{|c|}{$\begin{array}{c}\text { Ringa } \\
\mathrm{n}\end{array}$} & & & \\
\hline & $\mathrm{n}$ & $\%$ & $\mathrm{n}$ & $\%$ & $\mathrm{n}$ & $\%$ & \\
\hline $\begin{array}{l}\text { Umur } \\
\geq 35\end{array}$ & 28 & 90,3 & 3 & 9,7 & 31 & 100 & $0,0128,0$ \\
\hline $\begin{array}{l}\text { Tahun } \\
<35 \\
\text { Tahun }\end{array}$ & 7 & 10,3 & 6 & 2,7 & 13 & 100 & \\
\hline
\end{tabular}




\begin{tabular}{|c|c|c|c|c|c|c|}
\hline \multicolumn{7}{|c|}{ Jenis Kelamin } \\
\hline Wanita & 1275,0 & 425,0 & 16 & 100 & \multicolumn{2}{|c|}{$\begin{array}{l}0 \\
70 \\
2\end{array}$} \\
\hline Pria & 2382,1 & 517,9 & 28 & 100 & & \\
\hline \multicolumn{7}{|c|}{ Lama Kerja } \\
\hline$\geq 8 \mathrm{Jam}$ & 2392,0 & 28,0 & $\begin{array}{l}2 \\
5\end{array}$ & $\begin{array}{c}10 \\
0\end{array}$ & $\begin{array}{l}0, \\
02\end{array}$ & $\begin{array}{l}6, \\
70\end{array}$ \\
\hline$<8 \mathrm{Jam}$ & 1263,2 & 73,8 & $\begin{array}{l}1 \\
9\end{array}$ & $\begin{array}{c}10 \\
0\end{array}$ & 7 & 8 \\
\hline \multicolumn{7}{|c|}{ Masa Kerja } \\
\hline $\begin{array}{ll}\geq & 5 \\
\text { Tahun }\end{array}$ & 2392,0 & 28,0 & $\begin{array}{l}2 \\
5\end{array}$ & $\begin{array}{c}10 \\
0\end{array}$ & $\begin{array}{l}0, \\
02\end{array}$ & $\begin{array}{l}6, \\
70\end{array}$ \\
\hline $\begin{array}{ll}< & 5 \\
\text { Tahun }\end{array}$ & 1263,2 & 736,8 & $\begin{array}{l}1 \\
9\end{array}$ & $\begin{array}{c}10 \\
0\end{array}$ & 7 & 8 \\
\hline \multicolumn{7}{|c|}{ Aktivitas Berulang } \\
\hline $\begin{array}{l}\text { Ya } \\
\text { Tidak }\end{array}$ & $\begin{array}{cc}28 & 90,3 \\
7 & 53,8\end{array}$ & $\begin{array}{ll}3 & 9,7 \\
6 & 46,2\end{array}$ & $\begin{array}{l}31 \\
13\end{array}$ & $\begin{array}{l}100 \\
100\end{array}$ & $\begin{array}{c}0, \\
01 \\
2\end{array}$ & $\begin{array}{l}8, \\
0\end{array}$ \\
\hline \multicolumn{7}{|c|}{ Latihan Fisik } \\
\hline $\begin{array}{l}\text { Kurang } \\
\text { Rutin }\end{array}$ & 1666,7 & 833,3 & & 100 & $\begin{array}{c}0, \\
02 \\
7\end{array}$ & $\begin{array}{l}9 \\
5\end{array}$ \\
\hline Rutin & 1995,0 & 15,0 & 20 & 100 & & \\
\hline
\end{tabular}

Berdasarkan Tabel 2. didapatkan hasil uji statistik $p$ value $=0,012$, ini berarti ada hubungan yang bermakna antara umur dengan Musculoskeletal Disorders (MSDs) pada pekerja Tenun Ikat di Kelurahan Tuan Kentang Kota Palembang Tahun 2019. Dari hasil analisis diperoleh pula nilai OR = 8,000 , artinya pekerja yang berumur tua mempunyai peluang 8,000 kali lebih berisiko untuk mengalami musculoskeletal disorders dibandingkan pekerja yang berumur muda.

Salah satu yang mempengaruhi kerja otot pekerja yaitu umur. ${ }^{(2)}$ Hasil penelitian ini menunjukkan bahwa ada hubungan antara umur dengan keluhan muskuloskeletal, pekerja dengan umur $\geq 30$ tahun berisiko 4,4 kali mengalami keluhan muskuloskeletal tingkat tinggi dibanding pekerja dengan umur $<30$ tahun. ${ }^{(8)}$ Selain itu umur ditemukan tidak berhubungan dengan keluhan muskuloskeletal. ${ }^{(6)}$ Begitu juga hasil penelitian pada nelayan ditemukan tidak ada korelasi antara umur dengan keluhan otot. Kondisi ini disebabkan berkurangnnya kekuatan otot karena bertambahnya umur.

Berdasarkan Tabel 2. didapatkan hasil uji statistik $p$ value $=0,702$, ini berarti tidak ada hubungan yang bermakna antara jenis kelamin dengan musculoskeletal disorders (MSDs) pada pekerja Tenun Ikat di Kelurahan tuan Kentang Kota Palembang Tahun 2019.

Menurut Tarwaka (2015), walaupun masih ada perbedaan pendapat dari beberapa ahli tentang pengaruh jenis kelamin terhadap resiko keluhan otot skeletal, namun beberapa hasilpenelitian secara signifikan menunjukkan bahwa jenis kelamin sangat mempengaruhi tingkat resiko keluhan otot. Hal ini terjadi karena secara fisiologis, kemampuan otot wanita memang lebih rendah daripada pria. Astrand\& Rodahl (1977) menjelaskan bahwa kekuatan otot wanita hanya sekitar duapertiga dari kekuatan otot pria, sehingga 
daya tahan otot pria pun lebih tinggidibandingkan dengan wanita. Hasil penelitian Betti'e at al. (1989) menunjukkanbahwa rata-rata kekuatan otot wanita kurang lebih hanya $60 \%$ dari kekuatanotot pria, khususnya untuk otot lengan, punggung dan kaki. Hal ini diperkuatoleh hasil penelitian Chiang et al. (1993), Bernard et al. (1994), Hales et al.(1994) dan Johanson (1994) yang menyatakan bahwa perbandingan keluhanotot antara pria dan wanita adalah 1:3.Dari uraian tersebut di atas, makajenis kelamin perlu dipertimbangkan dalam mendesain beban tugas.

Hasil penelitian ini sejalan dengan penelitian yang dilakukan oleh Nuryaningtyas dan Tri (2014) jenis kelamin responden dalam penelitian ini mayoritas berjenis kelamin perempuan yang berjumlah 28 responden sedangkan responden yang berjenis laki-laki berjumlah 5 orang. Berdasarkan uji statistik tidak terdapat hubungan antara jenis kelamin dengan keluhan muskuloskeletal. Menurut Nusdwinuringtyas dalam jurnal Keperawatan (2009), menyatakan bahwa laki-laki dan perempuan memiliki risiko yang sama terhadap keluhan muskuloskeletal hingga usia 60 tahun, namun pada kenyataannya jenis kelamin seseorang dapat mempengaruhi timbulnya keluhan. Pada wanita keluhan ini lebih sering terjadi misalnya pada saat mengalami siklus menstruasi, selain itu proses menopause juga dapat menyebabkan kepadatan tulang berkurang.

Menurut hasil penelitian, teori dan penelitian terkait, peneliti berpendapat bahwa tidak ada hubungan antara jenis kelamin dengan MSDs karena tidak ada perbedaan antara jenis kelamin laki-laki dan perempuan untuk mengalami gangguan MSDs, tergantung dari aktivitas kerja dan beban kerja yang dikerjakannya.

Berdasarkan tabel 3.3 didapatkan hasil uji statistik $p$ value $=0,027$, ini berarti ada hubungan yang bermakna antara lama kerja dengan musculoskeletal disorders (MSDs) pada pekerja Tenun Ikat di Kelurahan tuan Kentang Kota Palembang Tahun 2019. Dari hasil analisis diperoleh pula nilai $\mathrm{OR}=6,708$, artinya pekerja yang lama kerjanya $\geq 8$ Jam mempunyai risiko 6,708 kali lebih besar untuk mengalami musculoskeletal disorders dibandingkan pekerja yang lama kerjanya <8 Jam.

Lama kerja adalah jumlah waktu terpajan faktor risiko. Lama kerja dapat dilihat sebagai menit-menit dari jam kerja/hari pekerja terpajan risiko. Lama kerja juga dapat dilihat sebagai pajanan tahun faktor risiko atau karakteristik 
pekerjaan berdasarkan faktor risikonya. (Utami, Siti, dan Nurnashriana, 2017)

Hasil penelitian ini sejalan dengan penelitian yang dilakukan oleh Utami, Siti, dan Nurnashriana (2017) berdasarkan analisis bivariat lama kerja dengan Kejadian Muskuloskeletal Disorders dengan kriteria tidak Normal (>8 jam) terdapat 33 responden $(78.6 \%)$ yang mengalami msds, sedangkan yang tidak mengalami Muskuloskeletal Disorders terdapat 9 responden $(21.4 \%)$, sedangan kriteria normal $(<8$ jam $)$ terdapat 9 Responden $(45.0 \%)$ yang mengalami muskuloskeletal disorders, sedangkan yang tidak mengalami msds terdapat 11 responden $(55.0 \%)$. Berdasarkan Dari uji chi square bahwa lama kerja dengan keluhan Muskuloskeletal Disorders memenuhi Syarat Chi square, menunjukan $\rho$ value $(0,019)<0,05$ maka $\mathrm{H} 0$ ditolak atau $\mathrm{H} 1$ diterima sehingga dapat disimpulkan bahwa terdapat hubungan yang bermakna antara lama kerja dengan muskuloskeletal disorders pada petani padi di Desa Ahuhu tahun 2017.

Hasil penelitian ini tidak sejalan dengan penelitian yang dilakukan oleh Randang, Dyah, Oksfriani (2017) menunjukan bahwa tidak terdapat hubungan antara lama kerja dengan keluhan musculoskeletal pada nelayan di desa Talikuran Kecamatan Remboken Kabupaten Minahasa. Hasil ini didasarkan pada uji korelasi person didapatkan $p$ value sebesar 0.692 dengan nilai $\alpha=0.05(\mathrm{p}>0.05)$. nilai $p$ value 0.692 lebih besar dibandingkan dengan nilai $\alpha(0.05)$.

Hasil penelitian ini sejalan dengan penelitian yang dilakukan oleh Lestari dan Yuantari (2013) hubungan antara lama duduk dengan keluhan subyektif nyeri pinggang 0,324 -0,186 Ho diterima dan $\mathrm{Ha}$ ditolak tidak ada hubungan antara lama duduk dengan keluhan subyektif nyeri pinggang, Lama kerja dapat berpengaruh terhadap cadangan energi sehingga perlu diimbangi dengan istirahat yang cukup dalam sehari. Istirahat yang cukup akan mengembalikan energi yang hilang selama bekerja. Mengacu pada lama istirahat yang direkomendasikan oleh pemerintah melalui Departemen perhubungan Direktorat Lalu Lintas Angkatan Darat untuk lama bekerja lebih dari 8 jam seharusnya lebih dari 1jam sehingga energi yang hilang pulih kembali. Dalam sehari pengemudi bus bekerja sebanyak 8-10 rit selama sehari, dengan waktu istirahat 10-15 menit tiap rit. Lama bekerja dalam sehari optimalnya 8 jam, atau 40-50 jam perminggu.

Menurut hasil penelitian, teori dan penelitian terkait, peneliti berpendapat bahwa ada hubungan antara lama kerja dengan MSDs dikarenakan semakin lama waktu yang diperlukan dalam melakukan pekerjaan maka akan semakin tinggi resiko 
yang akan diterima dan semakin lama waktu yang diperlukan untuk pemulihan tenaga, sehingga kesesuaian antara waktu bekerja dengan waktu istirahat harus sesuai agar mengurangi risiko MSDs.

Berdasarkan tabel 3.10 didapatkan hasil uji statistik $p$ value $=0,027$, ini berarti ada hubungan yang bermakna antara masa kerja dengan musculoskeletal disorders (MSDs) pada pekerja Tenun Ikat di Kelurahan tuan Kentang Kota Palembang Tahun 2019. Dari hasil analisis diperoleh pula nilai $\mathrm{OR}=6,708$, artinya pekerja yang masa kerjanya $\geq 5$ Tahun mempunyai risiko 6,708 kali lebih besar untuk mengalami musculoskeletal disorders dibandingkan pekerja yang masa kerjanya $<5$ Tahun.

Masa kerja adalah faktor yang berkaitan dengan lamanya seseorang berkerja disuatu perusahaan. Terkait dengan hal tersebut, MSDs merupakan penyakot kronis yang membutuhkan waktu lama untuk berkembang dan bermanifestasi. Jadi semakun lama waktu kerja atau semakin lama seseorang melakukan pekerjaan yang menonton maka makin besar tingkat risiko MSDs pada pekerja. Masa kerja memiliki hubungan yang kuat dengan keluhan otot dan meningkatkan risiko MSDs, terutama untuk pekerjaamn yang menggunakan kekuatan kerja yang tinggi. (2)
Hasil penelitian ini sejalan penelitian yang dilaporakan bahwa terdapat hubungan masa kerja dengan keluhan muskuloskeletal disorders. ${ }^{(6)}$ Gangguan pada otot muncul 2 tahun setelah bekerja dengan jenis pekerjaan yang sama. Pekerjaan yang sama merupakan pekerjaan yang menggunakan otot yang sama dalam waktu yang lama atau lebih dari 2 jam. Selain itu masa kerja berpengaruh terhadap keluhan musculoskeletal disorder's (MSDs) ini juga terjadi pada supir angkutan umum Gajah Mada Kota Medan. ${ }^{(10)}$ Begitu juga pada pekerja tenun ikat ditemukan pekerja yang mengalami keluhan MSDs yaitu pada pekerja yang lebih dari 5 tahun. Ini berarti bahwa semakin lama seseorang pekerja dengan aktivitas yang sama maka berpengaruh terhadap keluhan MSDs.

Berdasarkan Tabel 2 didapatkan hasil uji statistik $p$ value $=0,012$, ini berarti ada hubungan yang bermakna antara aktifitas berulang dengan Musculoskeletal Disorders (MSDs) pada pekerja Tenun Ikat di Kelurahan tuan Kentang Kota Palembang Tahun 2019. Dari hasil analisis diperoleh pula nilai $\mathrm{OR}=8,000$, artinya pekerja yang sering melakukan aktivitas

berulang mempunyai isiko 8,000 kali lebih besar untuk mengalami musculoskeletal disorders dibandingkan pekerja yang jarang melakukan aktivitas berulang. 
Aktivitas berulang adalah pekerjaan yang dilakukan secara terus menerus seperti pekerjaan mencangkul, membelah kayu besar, angkat-angkut dsb. Keluhan otot terjadi karena otot menerima tekanan akibat beban kerja secara terus menerus tanpa memperoleh kesempatan untuk relaksasi. ${ }^{(2)}$ Kondisi ini juga ditemukan pada pekerja tenun ikat dimana pekerja sering melakukan aktivitas berulang pada saat menenun kain. Aktivitas berulang saat menenun dapat menyebab gangguan sistem otot yang dialami pekerja, hal ini didukung dengan sarana seperti tempat duduk yang tidak ergonomis.

Berdasarkan tabel 3.5 didapatkan hasil uji statistik $p$ value $=0,027$, ini berarti ada hubungan yang bermakna antara kesegaran fisik dengan musculoskeletal disorders (MSDs) pada pekerja Tenun Ikat di Kelurahan Tuan Kentang Kota Palembang Tahun 2019. Dari hasil analisis diperoleh pula nilai $\mathrm{OR}=9,500$, artinya pekerja yang kurang rutin melakukan kesegaran fisik mempunyai risiko 9,500 kali lebih besar untuk mengalami musculoskeletal disorders dibandingkan pekerja yang rutin melakukan kesegaran fisik.

Latihan fisik merupakan gerakan yang berfungsi untuk meregangkan otot seseorang termasuk pekerja. Oleh karena itu untuk mencegah muskuloskeletal disorders penting dilakukan olahraga. Olahraga yang dianjurkan untuk mencegah muskuloskeletal disorders adalah low impact aerobic (seperti: jalan kaki, bersepeda dan berenang). Sebaiknya di lakukan 30-45 menit 3-5 kali seminggu yang diawali dengan pemanasan dan diakhiri dengan pendinginan. Hal ini dapat memperkuat otot dan mencegah muskuloskeletal disorders, sedangkan jika terjadi muskuloskeletal disorders maka sebaiknya dilakukan peregangan 1-2 kali sehari dan dilakukan secara rutin.

Menurut hasil penelitian, teori dan penelitian terkait, peneliti berpendapat bahwa terdapat hubungan antara aktifitas berulang dengan MSDs dikarenakan pekerja yang dalam melakukan pekerjaan secara terus menerus dan berulang ulang atau monoton mempunyai risiko bahaya yang tinggi untuk mengalami MSDs dan tingkat risiko akan bertambah jika pekerjaan dilakukan dengan beban kerja berat serta tenaga besar dalam waktu yang sangat cepat dan waktu pemulihan yang kurang.

Hasil penelitian ini ditemukan juga bahwa ada hubungan antara kebugaran jasmani dengan produktivitas kerja pada tenaga kerja wanita unit Spinning 1 bagian Winding PT. Apac Inti Corpora Bawen.(11) Bila organ tubuh mampu berfungsi secara normal dalam keadaan seseorang bergerak dan menjalankan tugas kerja, kondisi 
demikian diungkapkan dalam istilah sehat dinamis, dimana sehat dinamis merupakan tuntutan mutlak dalam kehidupan seharihari. Sehat dinamis merupakan pondasi bagi kebugaran yang memadai. Kerja menimbulkan kelelahan dan seterusnya terjadi pemulihan sehingga seseorang merasa bugar kembali dan siap untuk menjalankan tugas berikutnya.

Hasil penelitian ini sejalan dengan penelitian yang dilakukan oleh Nuryaningtyas dan Tri (2014) hubungan kebiasaan olahraga dengan keluhan muskuloskeletal disorders berdasarkan uji chi square, menyatakan bahwa tidak ada hubungan yang signifikan. Bila seseorang kurang berolahraga maka pada otot terjadi kelemahan dan kehilangan kelenturan dan bila olahraga dilakukan secara baik dan benar sesuai dengan anjuran dapat membantu meningkatkan kesegaran jasmani yang pada akhirnya akan meningkatkan ketahanan fisik (Soeparman, 2001, Moeloek, 1998 dalam Viyaya 2008). Oleh karena itu untuk mencegah muskuloskeletal disorders penting dilakukan olahraga. Olahraga yang dianjurkan untuk mencegah muskuloskeletal disorders adalah low impact aerobic (seperti: jalan kaki, bersepeda dan berenang). Sebaiknya di lakukan 30-45 menit 3-5 kali seminggu yang diawali dengan pemanasan dan diakhiri dengan pendinginan. Hal ini dapat memperkuat otot dan mencegah muskuloskeletal disorders, sedangkan jika terjadi muskuloskeletal disorders maka sebaiknya dilakukan peregangan 1-2 kali sehari dan dilakukan secara rutin.

\section{SIMPULAN}

Gangguan muskuloskletal pada pekerja Tenun Ikat di Kelurahan Tuan Kentang dipengaruhi oleh umur, lama kerja, masa kerja, latihan fisik dan aktivitas berulang.

Sebagai rekomendasi penting dilakukan latihan peregangan otot bagi pekerja untuk relaksasi otot, dan juga program gizi pekerja sangat diperlukan untuk meningkatkan sistem imun pekerja.

\section{DAFTAR RUJUKAN}

1. Tarwaka, Solichul H.A Bakri dan Lilik Sudiajeng, 2004. Ergonomi Untuk Kesehatan, Keselamatan Kerja dan Produktivitas. Surakarta: Uniba Press.

2. Tarwaka. 2015. Ergonomi Industri Dasar-Dasar Pengetahuan Ergonomi dan Aplikasi di Tempat Kerja, Badan Penerbit Harapan Press: Surakarta.

3. Kemenkes RI, 2014. Data Kecelakaan Kerja. Kemenkes RI : Jakarta. (online)

4. Depkes, 2005. Profil Masalah Kesehatan di Indonesia.

5. Evadariato, Nurdian \&Endang Dwiyanti. 
2017. Postur Kerja Dengan Keluhan Musculoskeletal Disorders Pada Pekerja Manual Handling Bagian Rolling Mill, The Indonesian Journal of Occupational Safety and Health, 6(1): 97-106.

6. Nuryaningtyas, Binarfika Maghfiroh dan Tri Martiana. 2014. Analisis Tingkat Risiko Muskuloskeletal Disorders (MSDs) Dengan The Rapid Upper Limbs Assessment (Rula) Dan Karakteristik Individu Terhadap Keluhan MSDs (Online), The Indonesian Journal of Occupational Safety and Health, 3(2): 160-169

7. Elvida, Maria Nova. 2015. Pembuatan Kain Tenun Ikat Maumere Di Desa Wololora Kecamatan Lela Kabupaten Sikka Propinsi Nusa Tenggara Timur, Jurnal Holistik, 8(16)

8. Rahayu, Winda Agustin. 2012. FaktorFaktor Yang Berhubungan Dengan Keluhan Muskuloskeletal Pada Pekerja Angkat-Angkut Industri Pemecahan Batu Di Kecamatan Karangnongko Kabupaten Klaten, Jurnal Kesehatan Masyarakat, 1 (2):836 - 844 .

9. Randang Jesika M \& Dyah Ratih S. 2017. Hubungan antara umur, masa kerja, dan lama kerja dengan keluhan musculoskeletal pada nelayan do desa talikuran kecamatan remboken Kabupatwn Minahasa. Jurnal FKM Universitas Ratulangi, (http://www.ejournalhealth.com/index.ph p/medkes/article/viewFile/292/284, diakses: 1 Maret 2019 pukul 15.06 WIB)

10. Ferusgel A \& Rahmawati, 2018. Faktor Yang Mempengaruhi Keluhan Musculoskeletal Disorders Pada Sopir Angkutan Umum Gajah Mada Kota Medan. Jurnal Universitas Tadulako, 9(2).

11. Utami, Sri Rahayu. 2012. Status Gizi, Kebugaran Jasmani Dan Produktivitas Kerja Pada Tenaga Kerja Wanita, Jurnal Kesehatan Masyarakat, KEMAS, 8 (1) :74-80

(http://journal.unnes.ac.id/nju/index.php/ kemas, diakses pada 05 Mei 2019 pukul 15.45 WIB)

12. Lestari, Yunita Wiji dan MG Catur Yuantari. 2013.Keluhan Subyektif Nyeri Pinggang Pada Pengemudi Bus, Jurnal Visikes, 12(1).

(http://ejournals1.undip.ac.id/index.php/j $\underline{\mathrm{km}}$, diakses pada 01 Maret 2019 pukul 14.06 WIB)

13. Utami, Ucik, Siti Rabbani Karimuna dan Nurnashriana Jufri. 2017. Hubungan lama kerja, sikap kerja, dan beban kerja dengan Muskuloskeletal Disorders (MSDs) pada petani padi di desa Ahuhu Kecamatan Meluhu Kabupaten Konawe Tahun 2017, Jurnal Ilmiah Mahasiswa Kesehatan Masyarakat, 2 (6). 